\title{
THE DYNAMICS OF LANGUAGE ATTITUDES OF THE TEENAGERS AT DESA BUDUK, BADUNG TO BALINESE LANGUAGE
}

\author{
I Nyoman Muliana \\ Universitas Warmadewa \\ inyomanmulianabali@gmail.com \\ Made Subur \\ Universitas Warmadewa \\ madesubur877@gmail.com \\ Anak Agung Gede Suarjaya \\ Universitas Warmadewa \\ mynsuar@gmail.com
}

\begin{abstract}
This research has the background of the phenomena of local languages claimed to decrease in numbers these decades. It aims to explore the dynamics of language attitudes of the teenagers at Desa Buduk, Badung and the factors causing the dynamics supported by using theory of Language Attitudes of Ladegaard (2000). The methods applied in this research included survey and participative observation. The results of the research show that the language attitudes of the teenagers to Balinese language are dynamic. The quantitative analysis indicates that $80 \%$ of them strongly agreed to the statements of cognitive language attitudes about Balinese language and its speakers. Then, $80 \%$ of them also agreed to the statements of affective language attitudes language concerning with preference in using Balinese language, but they disagreed the statements of greetings using other language than Balinese language and news on TVs and radios using other language than Balinese language and news. They also had positive for the statement in conative language attitudes concerning with the transfer of Balinese language to their children, but in that component of language attitude they were negative for statements about responses of using Balinese language only, admonishing people using other language, and switching off TV or radio using languages other than Balinese. The qualitative analysis of this research shows that most teenagers at Desa Buduk, Badung had positive language attitudes to Balinese language indicated by their behaviors using Balinese language. But, some high class teenagers showed the use of Indonesian language. The dynamics of the language attitudes of the teenagers at Desa Buduk, Badung to Balinese language by language loyalty, language value, and residential density.
\end{abstract}

Keywords: teenagers; local language; language attitudes

\section{INTRODUCTION}

Language becomes an essential part of humans. It fills almost every single of their activities. People use language for various purposes, they language for expressing their ideas, feelings, experiences. Language is vehicle of thought having form of a system mediating the transfer of thoughts (Finegan \& Besnier, 1989). Besides that, they also take advantages from language in making relations with other peoples both inside and outside their social groups. For those purposes, language is also learnt in order that the use of language in that purposes can be successful. People learn a language in their social group in order they can communicate very with other people in the group. Language has general function in social communication because there is always communication or interrelation among the member of the social group (Soeparno, 2013). On the other hand, people also learn a language of the other group that is used for 
communication with people from the other group. Both processes of language acquisitions certain require processes and situations.

Language attitude is a situation one has toward his or others' language. As to other things such as clothes or, someone can feel sensitive to their language or others language. Language attitude is a belief and people can react in a manner they prefer to a language (Anderson, 1979). People can feel positive when they find a language is good and they can also feel negative when they find a language is not good. Language attitude can refer to an attitude to language of a social group or the speakers of the language (Appel \& Muysken, 1987). The representative concept of language attitude needed in this research is proposed by Jendra stating that language attitude can be realised in the form of how people maintain their language by using it everyday (Bawa \& Jendra, 1981). The concept of language attitude proposed by Jendra reflects attention to local languages which is claimed to decay in numbers. The phenomena has become an important issue among linguists all over the world at the aims of finding efforts of maintaining local languages.

Researches on language attitude have been conducted both in Indonesia and abroad. A research on language attitudes of senior school students toward Indonesian language: a case study at SMA Negeri 1 Singaraja finding that the conative aspect of the students' language attitudes were negative, the affective aspects were positive, the cognitive aspects were neutral, and the attitudes were caused by internal and external factors (Wardani, A.K.D.K. et al., 2013). Wulandari et al made a research on language attitudes of Islamic boarding school students in the context of Javanese language maintenance in teaching process of the school, a case at Islamic boarding schools in Semarang City. In the research Wulandari et al found that the students had positive language attitudes to Javanese language and their positive attitudes were caused by their communications with the Islamic priests at the schools (Wulandari \& Al., 2012). Liu et al did a research on current language attitudes of Mainland Chinese University Students. Liu's research shows that the students had positive language attitudes to
English(Liu \& Zhao, 2011). Other related research is conducted by Amin at al on the language shift and language maintenance of mother tongue in family domain in Semarang where they found that some migrants maintained their mother tongues (Amin \& Suyanto, 2017).

This research of language attitudes among the teenagers at Desa Buduk, Badung to Balinese language was based on the phenomena of the existence of local languages among their speakers. It was conducted to find answers for the two problems, they are the language attitudes of the teenagers to Balinese language and the factors causing their attitudes to Balinese language. The research was supported with the theory of Language Attitudes proposed by Ladegaard who developed the theory of language attitude into a tripartite model as the following chart (Ladegaard, 2000).

Picture 1. Language Attitudes proposed by Ladegaard

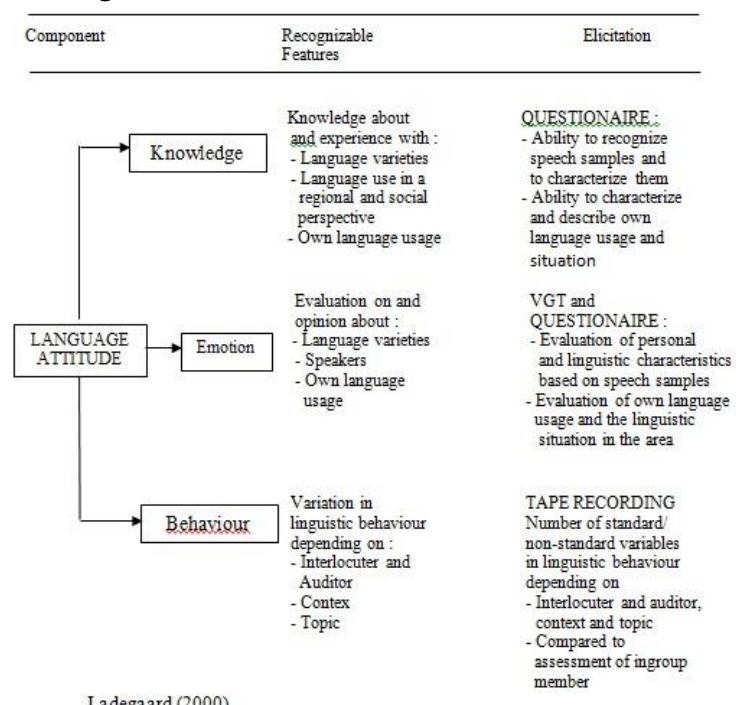

The research aims at answering the phenomena of language attitudes among the teenagers at Desa Buduk, Badung to Balinese language. As a part of efforts in conserving local languages, such researches must be conducted in particular with the subjects of the young generation because they are the key generation in local language conservation (Sumarsono, 1993). In order to get comprehensive results the research method applied in this research included both quantitative and qualitative research approaches. 


\section{METHOD}

This research required both quantitative and qualitative research approaches. The quantitative approach was realized in using survey method for collecting the respondents' self reports about their language attitudes (Mahsun, 2005). The survey method was carried out by utilizing research questionnaires having 4 statements for each component of language attitudes, they are cognitive, affective, and conative so that there are 12 statements of language attitudes. The 12 numbers of the statements in the questionnaires were considered sufficient to explore information from the respondents. The respondents of the research consisted of 20 teenagers randomly taken from the ten units of the village of Desa Buduk, Kecamatan Mengwi, Kabupaten Badung. The respondents were also classified into high and low social classes determined from their family backgrounds (Suhardi, 2009). The data obtained from the survey method were then analysed quantitatively to get percentage of the choices of the respondents to the statements provided in the research questionnaires. The result of the analysis is presented formally in tables. The survey method was then completed with participative observation method. This method of the research was used to explore the uses of language realized by the presence of the researcher among the informants so that real language uses could be observed properly. The data of the participative observation was analysed and presented descriptively by using descriptions of sentences.

\section{DISCUSSION}

\section{Cognitive Language Attitude}

Cognitive language attitude is about how people view language and its speakers. A language can be viewed as a difficult/an easy language and the speakers can be viewed as smart/ugly people. The statements for cognitive language attitude used in this research are as the followings.
1) Balinese language is important to show our identity as Balinese ethnic people.

2) Balinese language is not difficult and it is easy for us to find its vocabularies.

3) People speaking in Balinese language do not look old-fashioned.

We do not respect our ancestors if we as Balinese people do not use Balinese language.

The analysis of cognitive language attitudes of the teenagers at Desa Buduk, Kecamatan Mengwi, Kabupaten Badung can be seen in the following table.

Table 1. Cognitive Language Attitude

\begin{tabular}{|c|c|c|c|c|c|}
\hline \multirow{2}{*}{ Statements } & \multicolumn{5}{|c|}{ Responses } \\
\cline { 2 - 6 } & Strongly Agree & Agree & Neutral & Disagree & Strongly Disagree \\
\hline 1 & $67 \%$ & $15,3 \%$ & $0 \%$ & $2.4 \%$ & $6.3 \%$ \\
\hline 2 & $81.7 \%$ & $13 \%$ & $0 \%$ & $3.3 \%$ & $1 \%$ \\
\hline 3 & $73 \%$ & $18.3 \%$ & $2.3 \%$ & $8.4 \%$ & $7 \%$ \\
\hline 4 & $80 \%$ & $16.3 \%$ & $0 \%$ & $4 \%$ & $2.7 \%$ \\
\hline
\end{tabular}

Table 1 shows that the respondents had very positive cognitive language attitudes to Balinese language. It can be seen from the percentages found from choices the respondents made to the responses for the statements of cognitive language attitudes in this research. The highest percentages were made to the response "strongly agree" with $81.7 \%$ for the second statement meaning that most respondents did view that Balinese language as a difficult language.

\section{Affective Language Attitude}

Affective language attitude is about preference to a kind of language. People can feel that they like/dislike or shy/not shy to use a language. The data of the affective language attitudes of the respondents of this research was obtained with the following statements.

1) I prefer to use Balinese language for conversations with Balinese people.

2) I do not feel shy to use Balinese language in front of people of different ethnics.

3) I do not like to be greeted with other language other than Balinese language.

4) I prefer to have TV or radio news using Balinese language.

Quantitative analysis of affective language attitudes of the respondents of this research can be seen in the following table. 
Table 2. Affective Language Attitude

\begin{tabular}{|c|c|c|c|c|c|}
\hline \multirow{2}{*}{ Statements } & \multicolumn{5}{|c|}{ Responses } \\
\cline { 2 - 6 } & Strongly Agree & Agree & Neutral & Disagree & Strongly Disagree \\
\hline 1 & $82 \%$ & $10.3 \%$ & $2 \%$ & $3.3 \%$ & $2.4 \%$ \\
\hline 2 & $85.7 \%$ & $10 \%$ & $0 \%$ & $3.1 \%$ & $1.2 \%$ \\
\hline 3 & $3 \%$ & $12.3 \%$ & $0 \%$ & $21.7 \%$ & $63 \%$ \\
\hline 4 & $3 \%$ & $6,3 \%$ & $0 \%$ & $70.2 \%$ & $20.5 \%$ \\
\hline
\end{tabular}

The respondents of this research very dynamic situations of affective language attitudes. As shown in Table 2, the respondents' choices vary for the statements of this language attitude component. They seem to accept the statement 1 stating that they prefer to use Balinese language and statement 2 stating that they do not feel shy to use Balinese language in front of people of other ethnic backgrounds. The respondents were very positive in affective language attitudes with the two statements. On the other hand, the respondents' affective language attitudes are very negative to statement 3 stating that they do not like to be greeted with language other than Balinese language and statement 4 stating that they prefer to have $\mathrm{TV}$ or radio news in Balinese language. It seems that most of the respondents cannot accept the uses of Balinese language in that situations as stated in statement 3 and statement 4.

\section{Conative Language Attitude}

Conative language attitude is different from cognitive language attitude and affective language attitude. The conative language attitude is a concrete component that it can be seen in behaviours of actions or using language. The data of conative language attitudes of this research were taken by using the following statements.

1) I will always give answers in Balinese language whenever I am invited to talk in other language other than Balinese by Balinese people.

2) I will always admonish Balinese people who talk in Indonesian language.

3) I will always switch off TV or radio presenting programs in other language other than Balinese language.

4) When having child, I will teach him/her to use Balinese language.
Tabel 3. Conative Language Attitude

\begin{tabular}{|c|c|c|c|c|c|}
\hline \multirow{2}{*}{ Statements } & \multicolumn{5}{|c|}{ Responses } \\
\cline { 2 - 6 } & Strongly Agree & Agree & Neutral & Disagree & Strongly Disagree \\
\hline 1 & $1.2 \%$ & $3.5 \%$ & $0 \%$ & $5,3 \%$ & $90 \%$ \\
\hline 2 & $6 \%$ & $3 \%$ & $4 \%$ & $15.6 \%$ & $69.5 \%$ \\
\hline 3 & $0 \%$ & $1.3 \%$ & $0 \%$ & $12.7 \%$ & $86 \%$ \\
\hline 4 & $60 \%$ & $26,3 \%$ & $0 \%$ & $10 \%$ & $4,7 \%$ \\
\hline
\end{tabular}

The result of data analysis of conative language attitudes in this research can be seen in Table 3 . The respondents show very negative conative language attitude to Balinese language as can be seen at their responses to three statements 1 to statement 3 of the attitude component. They could not accept the statement 1 stating that they would give answers in Balinese language whenever I am invited to talk in other language other than Balinese by Balinese people. This statement is intentionally made in such meaning, but it could not be accepted by the respondents. They showed very positive language attitude for the statement 3 stating that when having child, they would teach him/her to use Balinese language. This fact reflects that the respondents had commitment in transferring Balinese language to their children as an important effort in conserving the language.

\section{Language Uses}

The analysis of language use by teenagers at Desa Buduk, Kecamatan Mengwi, Kabupaten Badung is made to support the analysis of their language attitudes. The data of the language uses analysis were obtained by applying participative observation method and that is why the analysis made here is filled with data of conversations. The three data below are used to support the analysis of language use.

Data 1

Topic

Lokasi

: Buying parachute cloth

: At a shop

Adik : Dija nak meli parasut?

Where is the place to buy parachute cloth?

Doble : Dija gen ada.

It is there everywhere.

Adi : Ci dija meli? Where did you buy?

Doble : Di sempidi. At Sempidi.

Iwan : Sid Pak Rai sing ada? Is there one at Pak Rai?

Doble : Ada. 
Yes, there is.

Data 1 is a conversation of the teenagers at Desa Buduk, Kecamatan Mengwi, Kabupaten Badung. The conversation occurred at one of the teenagers at one evening when they met and talked about buying parachute cloth as material of kite. There four teenagers involved in the conversation were all Balinese, males, and they were all from low class families. The language they used for talking about the topic at the conversation was Balinese with informal or casual variety. The use of the Balinese language variety in the conversation of data 1 can be seen from the use of words belonging to informal variety of Balinese language.

A similar data of language use by the teenagers at Desa Buduk, Kecamatan Mengwi, Kabupaten Badung was found in this research as seen in the data 3 below.

Data 2

\begin{tabular}{|c|c|c|}
\hline Topik & & : Trade \\
\hline Lokasi & & : At an informant's house \\
\hline & Pasek & $\begin{array}{l}\text { Peng medagang jani. } \\
\text { Peng is trading now. }\end{array}$ \\
\hline & Tisen & $\begin{array}{l}\text { Tamune kone konya cancel. } \\
\text { It's said that many guests } \\
\text { cancelled their visits. }\end{array}$ \\
\hline & Pasek & $\begin{array}{l}\text { Jani konya lockdown. Nyen } \\
\text { bani mai. } \\
\text { All are locked down now. } \\
\text { Who dares to come. }\end{array}$ \\
\hline & Adi & $\begin{array}{l}\text { : Liu nak medagang jani. } \\
\text { Many people are trading } \\
\text { now. }\end{array}$ \\
\hline & Pasek & $\begin{array}{l}\text { : Keweh mase nok. } \\
\text { It is difficult. }\end{array}$ \\
\hline & Wika & $\begin{array}{l}\text { To Mita liu timpane ngorin } \\
\text { ngendorse. } \\
\text { Many friends of Mita asked } \\
\text { her to do endorses. }\end{array}$ \\
\hline
\end{tabular}

Conversation at data 2 involved four teenagers at Desa Buduk, Kecamatan Mengwi, Kabupaten Badung. It took place at one of the teenagers' house where they talked about trading. The participants at the conversation of data 2 were Balinese ethnic people, all were males, and they were from different social background. Three of the participants in the conversation of data 2 were from low class families and one was from a high class family. The language they used in the conversation of data 2 is Balinese even though one of them was from a high class family. In the conversation it can also be seen that the Balinese language has informal or casual variety. The use of Balinese language in the conversation of data 2 also shows the phenomena of code mixing, the insertion of elements of a language into other language. In the conversation the elements are the words "cancel" and "ngendorse" that can be caused by the conversation was with a modern topic and the participants were already familiar with the words that there they also mixed Balinese prefix $\{n g-\}$ attached in morfem "endorse" (Bawa, et al, 1981).

A different language use was found in the participative observation in this research such as shown in data 3 below.

Data 3

Topik

Lokasi

: Gita's school

: At an informant's house

Ade : Gitanya ndak pulang dia?

Didn't Gita go home?

Ika : Ndak. Belum dikasi pulang.

No. she did not have any permission yet.

Ade : Kalau nelpon dikasi? Is it allowed to call her?

Ika : Sering. Tadi dia messenger. Often. She did messenger just now

Dinda : Sekolah apa itu, Mbok Ka? What school is it, Mbok Ka?

Ika : Pelayaran. Sailing.

Ade : Di kapal cruise?

At cruise ship?

Ika : Ndak. Di kapal ikan.

No. At a sailing ship.

Dinda : Wah hebat.

Wow. Great.

The conversation of data 3 involved a group of 3 teenagers at Desa Buduk, Kecamatan Mengwi, Kabupaten Badung. They consisted of two females and 1 male, and all of them were from high class family. The three of them had relation as friends. At the conversation they talked a topic about Gita's school at the house of one of the participants. In that conversation all participants used Indonesian language with its informal variety that can be caused by the situation of the conversation that was very informal and intimate. The use of Indonesian 
language at the conversation also shows phenomena of code mixing where the participants inserted English words into their Indonesian sentences. The English words are "messenger" and "cruise" which have been familiar to the participants. The use of Indonesian language in the conversation can be a reflection that there is a relation between social status and language choice. In that conversation, all participants were all from high class family and they made a choice of Indonesian language for their conversation.

\section{Factors of the Dynamics of Language Attitudes of the Teenagers at Desa Buduk, Badung to Balinese Language}

There are three factors of the dynamics of language attitudes of the teenagers at Desa Buduk, Kecamatan Mengwi, Kabupaten Badung, Bali to Balinese language. The first factor is language loyalty. Language loyalty is a situation at which speakers use their language continuously in accordance with its functions based on domains of language use. As a local language, Balinese language is mainly used in family, neighbourhood, and friendship domains. The teenagers at Desa Buduk, Kecamatan Mengwi, Kabupaten Badung show the factor of loyalty that they use Balinese language in communications with their family, their neighbours, and their friends. The second factor is language value meaning that a language can have an essential value to the speakers as a society having a culture. In many societies, language takes an important role as the means of communication of the culture. There almost all terms of the culture cannot be expressed with other language. The teenagers at Desa Buduk, Kecamatan Mengwi, Kabupaten Badung, Bali did realise this relation so that they had views that Balinese language is part of their ancestor and must be transferred to their next generation. The third factor is intimacy meaning that there is a close relations among people as family or as friends. Many things or activities are usually used in building intimacy, one of them is language that people will feel a close relation when they use certain language. The factor of intimacy affecting the dynamics of language attitude can also be found at in the relations as part the conative component is because the teenagers the teenagers Desa
Buduk, Badung. Most of them still used their Balinese language in communications with their Balinese friends. The last factor of the language attitudes of the teenagers Desa Buduk, Badung to Balinese language is residential density. The situation of the houses where people live can support the use and their attitudes to their language because it will influence the frequency they can meet each other. The teenagers at Desa Buduk, Badung live at houses which are very close that enable them to meet and use their Balinese language very frequently.

\section{CONCLUSION}

The quantitative and qualitative analysis of the research give conclusions about the dynamics of language attitudes of the teenagers at Desa Buduk, Badung described as the following.

1. The language attitudes of the teenagers at Desa Buduk, Badung to Balinese language are dynamic. The dynamics of the language attitudes of the teenagers to Balinese language can be proved from the results of the two analysis in this research, they are the quantitative and the qualitative analysis. The quantitative analysis shows that the teenagers at Desa Buduk, Badung had very positive language attitudes to Balinese language. $80 \%$ of the teenagers strongly agreed to the statements of cognitive language attitudes about Balinese language and its speakers. $80 \%$ of them also agreed to the statements of affective language attitudes concerning with preference in using Balinese language, but they seemed to disagree the statements of greetings addressed to them using other language than Balinese language and news on TVs and radios using other language than Balinese language and news. They also had positive for the statement in conative language attitudes concerning with the transfer of Balinese language to their children an significant factor for the conservation of Balinese language. As investigated by Indra, the Javanese 
language in Singaraja was lost because there was not any transfer to the next generation (2002). But in that component of language attitude they showed negative language attitudes for statements about responses of only using Balinese language, admonishing people using other language, and switching off $\mathrm{TV}$ or radio using languages other than Balinese. The qualitative analysis of this research shows that the teenagers at Desa Buduk, Badung had positive language attitudes to Balinese language indicated by their behaviors using Balinese language. But, the qualitative analysis of the research also shows that the high class of the teenagers tended to use Indonesian language.

2. The dynamics of the language attitudes of the teenagers at Desa Buduk, Badung to Balinese are caused by the following factors. First, they are caused by language loyalty indicated by their behavior of using Balinese language in their daily communications. Second, dynamics of language attitudes of the teenagers at Desa Buduk, Badung to Balinese language are caused by language value that is shown by their awareness and behavior in using Balinese language. the last factor is residential density as a significant situation for the teenagers to meet and use Balinese language frequently.

\section{REFERENCE}

Amin, M. F., \& Suyanto. (2017). Pemertahanan dan Pergeseran Bahasa Ibu dalam Ranah Rumah Tangga Migran di Kota Semarang. Nusa: Jurnal Ilmu Bahasa Dan Sastra, 12(1).

Anderson, E. A. (1979). Sikap Bahasa. Bahan Penataran Morfologi Sintaksis I. PPPB.
Appel, R., \& Muysken, P. (1987). Language and Bilingualism. (Colset Private Limited (ed.)).

Bawa, I. W., \& Jendra, I. W. (1981). Strukur Bahasa Bali. Pengembangan, Pusat Pembinaan dan Kebudayaan., Bahasa Departemen Pendidikan dan.

Finegan, E., \& Besnier, N. (1989). Language Its Structure and Use. Harcourt Brace Jovanovich, Inc.

Ladegaard, H. J. (2000). Language Attitudes and sociolinguistic behaviour : Exploring attitude-behaviour relations in language. Journal of Sociolinguistics.

Liu, M., \& Zhao, S. (2011). Current Language Attitudes of Mainland Chinese University Students. Journal of Language Teaching and Research, 2(5).

Mahsun, M. S. (2005). Metode Penelitian Bahasa Tahapan, Strategi. Metode, dan Tekniknya. PT. RajaGrafindo Persada.

Soeparno. (2013). Dasar-Dasar Linguistik Umum. Penerbit Tiara Wacana.

Suhardi, B. (2009). Metode Penelitian Sosiolinguistik. Pusat Bahasa Departemen Pendidikan Nasional.

Sumarsono. (1993). Pemertahanan Bahasa Melayu Loloan. Pusat Bahasa.

Wardani, A.K.D.K., Gosong, M., \& Artawan, G. (2013). Sikap Bahasa Siswa terhadap Bahasa Indonesia Studi Kasus di SMA Negeri $1 \quad$ Singaraja. https://www.neliti.com/publications/206 910/sikap-bahasa-siswa-terhadapbahasa-indonesia-studi-kasus-di-smanegeri-1-singara

Wulandari, \& Al., E. (2012). Konteks Pemertahanan Bahasa Jawa dalam Proses Pengajaran di Pesantren (Studi Kasus pada Pesantren-Pesantren di Semarang). http://eprints.undip.ac.id/43120/1/LAPO RAN_AKHIR_Penelitian_pembinaan.p df. 